\title{
Synergistic effect of Chryseobacterium gleum sp. SUK with ACC deaminase activity in alleviation of salt stress and plant growth promotion in Triticum aestivum $\mathbf{L}$.
}

\author{
Komal K. Bhise ${ }^{1} \cdot$ Prashant K. Bhagwat $^{1} \cdot$ Padma Babulal Dandge $^{2}$
}

Received: 10 October 2016/ Accepted: 8 May 2017/Published online: 30 May 2017

(C) Springer-Verlag Berlin Heidelberg 2017

\begin{abstract}
Soil salinity is major abiotic stresses affecting morphological, biochemical and physiological processes of plant growth. Chryseobacterium gleum sp. SUK isolated from salt-stressed soil exhibited ACC (1-aminocyclopropane-1-carboxylate) deaminase activity with IAA (indole acetic acid), siderophore, ammonia, hydrogen cyanide production, $2 \%$ salt tolerance and fungal cell wall degrading enzyme production (cellulase, protease). The isolate also showed a poultry feather degrading activity which is the main waste material of poultry industry and opulent source of proteins, amino acids, nitrogen, phosphorous, calcium, potassium, manganese, zinc and copper. Application of feather-degraded lysate with the degrading isolate, C. gleum sp. SUK denotes triple role of bioformulation to surmount salinity stress, management of poultry waste disposal and utilization of feathers degraded products as a biostimulant for better growth of plants as well as strain SUK having multifarious plant growth promoting traits. Wheat crops exposed to salt stressor were inoculated with studied bioformulation. Results of plant analysis showed improvement in root and shoot length, fresh and dry weight, chlorophyll, proteins, amino acids, phenolics, flavonoids content and decreased level of proline. In addition, $\mathrm{Na}^{+}$uptake was decreased and $\mathrm{K}^{+}$uptake was increased. Therefore, application of novel bioformulation could increase the yield of crops by ameliorating growth of plants and alleviating the salinity stress.
\end{abstract}

Padma Babulal Dandge

pbd_biochem@unishivaji.ac.in

1 Department of Microbiology, Shivaji University, Kolhapur 416004, Maharashtra, India

2 Department of Biochemistry, Shivaji University, Kolhapur 416004, Maharashtra, India
Keywords Salinity stress · Poultry feathers · Chryseobacterium gleum sp. SUK · Bioformulation · Wheat crops

\section{Introduction}

Plant growth promoting bacteria (PGPB) are the diverse group of micro-organisms living in plant rhizosphere and have been widely studied for increasing agricultural productivity (Lucy et al. 2004). These PGPB influence the growth and development of plants by various mechanisms which includes atmospheric nitrogen fixation, phosphate solubilization, production of ACC deaminase, phytohormones, siderophore, hydrogen cyanide ( $\mathrm{HCN})$, antibiotics, hydrolytic enzymes and organic molecules (Babalola 2010). In addition to growth, PGPB have the ability to help the plant to tolerate abiotic stress such as soil salinity (Yang et al. 2009).

Salt stress is one of the abiotic stresses which affects growth of plants, reflected as serious agriculture problem (Hu and Schmidhalter 2005). In India, wheat (Triticum aestivum L.) is a main cereal crop and its overall growth is reduced by salinity stress resulting in the loss of around $65 \%$ yield (Shafi et al. 2010). Plants exposed to salt stressor affected soil produces increased ethylene level to initiate apoptosis (Trobacher 2009) which ultimately leads to tissue senescence. PGPB with ACC deaminase activity when present in rhizosphere metabolize ACC (ethylene precursor) into ammonia and $\alpha$-ketobutyrate which help the plants to survive in stress condition (Mayak et al. 2004).

Nowadays, the gradual increase in poultry industries resulted in the generation of chicken feathers as a waste in a millions of tones (Williams et al. 1990). This huge 
quantity of waste materials is either dumped by landfilling, or incinerated which causes pollution problems and also loss of useful nutrients such as protein and enzymes. (Lasekan et al. 2013). Feathers are rich and cheap source of proteins and may function as effective biofertilizer; this fact is responsible for interest of many researchers to prepare feather-based biofertilizer (Tiwary and Gupta 2010). Feathers can be degraded by bacteria and formed lysate having amino acids and peptides can be used as biostimulant to increase nutrient uptake, growth of plants as well as to tolerate abiotic and biotic stress to increase overall crop yield (Vernieri et al. 2006). The degraded feather lysate could generate tryptophan in appreciable amount which is precursor of plant hormone IAA (Tsavkelova et al. 2012).

With this theme, we have isolated ACC deaminase producing isolate from soil; the isolate was investigated for plant growth promoting traits (PGPT) (Phosphate solubilisation, production of IAA, siderophore, ammonia, HCN, etc.) and for feather degradation ability. The effect of inoculum containing Chryseobacterium gleum sp. SUK with feather lysate on growth of wheat (T. aestivum L.) was evaluated for 15 and 30 days in the presence of $100 \mathrm{mM}$ of salt stressor and it was compared with wheat crops inoculated separately with only isolate under identical conditions.

\section{Materials and methods}

\section{Chemicals}

ACC was purchased from Sigma-Aldrich, India and all the standards like $\mathrm{KH}_{2} \mathrm{PO}_{4}$, IAA, L-proline, BSA (Bovine serum albumin), Gallic acid, Rutin and other media components were purchased from HiMedia, India. All the chemicals used in this study were of analytical grade.

\section{Isolation of ACC deaminase producers}

ACC-utilizing bacteria AF-2 was isolated from saline soil of Kolhapur, Maharashtra, India based on its ACC utilization ability following the method of Penrose and Glick (2003) with few modifications. Briefly, $1 \mathrm{~g}$ soil sample was enriched by inoculating in sterile DF salts (Dworkin and Foster 1958) medium supplemented with $3 \mathrm{mM}$ ACC as the sole nitrogen source and incubated at $30{ }^{\circ} \mathrm{C}$ for $24 \mathrm{~h}$ on a rotary shaker at $200 \mathrm{rpm} .0 .1 \mathrm{ml}$ aliquot of this enriched sample was plated onto solid DF salt agar medium containing ACC $(3 \mathrm{mM})$ and incubated at $30{ }^{\circ} \mathrm{C}$ for $48 \mathrm{~h}$. Bacterial colonies were purified and maintained onto the respective medium slants at $4{ }^{\circ} \mathrm{C}$. ACC deaminase activity was assayed quantitatively using the method of Honma and
Shimomura (1978). Amount of $\alpha$-ketobutyrate produced was determined by comparing absorbance of sample with standard curve of $\alpha$-ketobutyrate $(0.1-1 \mu \mathrm{mol})$ at $540 \mathrm{~nm}$.

\section{Characterization of isolate and 16S rDNA identification}

The morphological and biochemical property of AF-2 is given in Table 1. Gram staining and IMViC (Indole, Methyl Red, Voges Proskauer, Citrate utilization) tests were performed following the standard protocol (Prescott et al. 2002). Isolate AF-2 was identified by $16 \mathrm{~S}$ rDNA gene sequence analysis. The evolutionary history was inferred using the Neighbor Joining method (Saitou and Nei 1987). The evolutionary distances were computed using the Maximum Composite Likelihood method (Tamura et al. 2004) and were in the units of the number of base substitutions per site. Evolutionary analysis was conducted in MEGA6 (Tamura et al. 2013). The partial 16 S rDNA gene sequence was deposited in Gene Bank data base under accession number of KX396055.

\section{Determination of PGPT of AF-2}

\section{Phosphate solubilization}

Phosphate solubilization potential of AF-2 was analyzed quantitatively using Pikovskaya's (Pikovaskaya 1948) broth medium. Briefly, $100 \mathrm{ml}$ of Pikovskaya's liquid medium was inoculated with $1 \mathrm{ml}$ aliquot of seed culture and incubated under shaking condition at $30{ }^{\circ} \mathrm{C}$ for 7 days. Sterile uninoculated growth medium was used as control. After $24 \mathrm{~h}$, culture was harvested by centrifugation at $6000 \mathrm{rpm}$ for $15 \mathrm{~min}$. Amount of soluble phosphate in supernatant was quantified using the Fiske and Subbarow method (1925).

\section{IAA production}

The ability of isolate AF-2 to produce IAA was quantified using the method of Gorden and Weber ( 1951) with slight modification. $1 \mathrm{ml}$ aliquot of fresh culture was inoculated in $100 \mathrm{ml}$ Nutrient broth in $250 \mathrm{ml}$ Erlenmeyer flask supplemented with $0.2 \%$ of tryptophan and incubated at $30{ }^{\circ} \mathrm{C}$ for 6 days on rotary shaker. $2 \mathrm{ml}$ of broth was withdrawn after each $24 \mathrm{~h}$ of interval and centrifuged at $6000 \mathrm{rpm}$ for $15 \mathrm{~min}$. Further, $1 \mathrm{ml}$ of supernatant was added with 2 drops of orthophosphoric acid and $2 \mathrm{ml}$ of Salkowsky reagent $\left(1 \mathrm{ml} 0.5 \mathrm{M} \mathrm{FeCl}_{3}\right.$ in $50 \mathrm{ml}$ of $\left.35 \% \mathrm{HClO}_{4}\right)$. Absorbance of resulting pink color was measured at $540 \mathrm{~nm}$ using UV-Vis Spectrophotometer. The IAA concentration was determined from IAA standard curve (10-100 $\left.\mu \mathrm{g} \mathrm{ml}^{-1}\right)$. 
Table 1 Biochemical profile of AF-2

\begin{tabular}{|c|c|c|}
\hline Sr no. & Characteristics & $\mathrm{AF}-2$ \\
\hline \multicolumn{3}{|c|}{ Morphology } \\
\hline 1 & Gram nature & - \\
\hline 2 & Shape & Rod \\
\hline \multicolumn{3}{|c|}{ Biochemical reactions } \\
\hline 3 & Lactose & - \\
\hline 4 & Xylose & - \\
\hline 5 & Maltose & - \\
\hline 6 & Fructose & - \\
\hline 7 & Dextrose & - \\
\hline 8 & Galactose & - \\
\hline 9 & Raffinose & - \\
\hline 10 & Trehalose & - \\
\hline 11 & Melibiose & - \\
\hline 12 & Sucrose & - \\
\hline 13 & L-Arabinose & - \\
\hline 14 & Mannose & - \\
\hline 15 & Insulin & - \\
\hline 16 & Sodium gluconate & - \\
\hline 17 & Glycerol & - \\
\hline 18 & Salicin & - \\
\hline 19 & Dulcitol & - \\
\hline 20 & Inositol & - \\
\hline 21 & Sorbitol & - \\
\hline 22 & Mannitol & - \\
\hline 23 & Adonitol & - \\
\hline 24 & Arabitol & - \\
\hline 25 & Erythritol & - \\
\hline 26 & $\alpha$-Methyl-D glucoside & - \\
\hline 27 & Rhamnose & - \\
\hline 28 & Cellobiose & - \\
\hline 29 & Melezitose & - \\
\hline 30 & $\alpha$-Methyl-D mannoside & - \\
\hline 31 & Xylitol & - \\
\hline 32 & ONPG & + \\
\hline 33 & Esculin hydrolysis & + \\
\hline 34 & D-Arabinose & - \\
\hline 35 & Citrate utilization & + \\
\hline 36 & Malonate utilization & - \\
\hline 37 & Sorbose & - \\
\hline 38 & Indole test & + \\
\hline 39 & Methyl red test & - \\
\hline 40 & Voges-Proskauer & + \\
\hline 41 & Citrate utilization test & + \\
\hline
\end{tabular}

\section{Siderophore production}

Isolate AF-2 was spot inoculated on chrome azurole $\mathrm{S}$ (Schwyn and Neilands 1987) agar plates and incubated for
6-7 days at $30{ }^{\circ} \mathrm{C}$. Development of yellow-orange halo zone around the colony after incubation period was considered as positive for siderophore production.

\section{Ammonia production}

AF-2 isolate was inoculated separately into $5 \mathrm{ml}$ sterile peptone water and incubated at $30{ }^{\circ} \mathrm{C}$ for $48 \mathrm{~h}$. After the bacterial growth, Nessler's reagent $(0.3 \mathrm{ml})$ was added to each tube. Ammonia production was indicated by the development of brown to yellow color (Marques et al. 2010) and uninoculated medium was used as blank.

\section{Hydrogen cyanide production}

Bacterial isolate was spreaded on to King's agar plates (King et al. 1954). The Petri plates were covered with a lid having a slice of filter paper soaked in $1 \%$ picric acid and moistened with few drops of $10 \% \mathrm{NaCO}_{3}$ (Lorck 1948), plates were sealed with parafilm and incubated at $30^{\circ} \mathrm{C}$. Change in filter paper color from yellow to brown was considered as positive for cyanide production. Control plate was prepared without inoculation.

\section{Screening for salt tolerance}

The inherent resistance of AF-2 to salt stress was evaluated by streaking the fresh culture of isolate on Nutrient agar plates added with various concentration of $\mathrm{NaCl}(0.5,1$, $1.5,2,2.5$ and $3 \%$ ). The plates were incubated at $30{ }^{\circ} \mathrm{C}$ for $48 \mathrm{~h}$ and growth on $\mathrm{NaCl}$ added medium was compared over control (Nutrient agar plate).

\section{Production of fungal cell wall degrading enzymes}

\section{Protease production}

Protease production ability of AF-2 was checked on skim milk agar plates $(3 \% \mathrm{w} / \mathrm{v})$. A single colony was inoculated on this medium and incubated at $30{ }^{\circ} \mathrm{C}$ for $72 \mathrm{~h}$. Protease activity was detected as a clear zone around the growth (Chang et al. 2009).

\section{Chitinase production}

Production of chitinase was determined using the method described by El-Hamshary et al. (2008). Bacterial isolate was spotted on $1 \%$ colloidal chitin agar plates and incubated at $30{ }^{\circ} \mathrm{C}$ for 7 days. After the incubation period, chitinase production was detected by the formation of a clear zone after adding $0.1 \%$ congo red solution onto plates. 


\section{Cellulase production}

Cellulase activity of AF-2 isolate was checked by inoculation on $1 \%$ carboxy methyl cellulose agar plates and incubation at $30{ }^{\circ} \mathrm{C}$ for $48 \mathrm{~h}$. Development of clear zone followed by addition of iodine $(0.666 \% \mathrm{KI} ; 0.333 \%$ iodine $)$ for 5 min was considered as positive for cellulase activity (Kasana et al. 2008).

\section{Feather degradation ability}

The ability of AF-2 to utilize poultry waste (Chicken feathers) was tested by culturing into the BSM (Basal salt medium) supplemented with $1 \%$ poultry feathers as sole nitrogen source and incubated at $30{ }^{\circ} \mathrm{C}$ for 7 days under shaking conditions (120 rpm). After each $24 \mathrm{~h}$ keratinase activity, released proteins and amino acids were evaluated. Uninoculated medium was used as control.

\section{Keratinase assay}

The ability of the isolate to produce keratinase was assayed as per the protocol of Hossain et al. (2007). $1 \mathrm{ml}$ of crude enzyme was diluted with Tris-HCl buffer $(\mathrm{pH} 8.5)$ and added with $1 \mathrm{ml}$ of standard keratin $(0.1 \%)$. The reaction was terminated by adding $2.0 \mathrm{ml}$ trichloroacetic acid $(0.4 \mathrm{~mol} / \mathrm{l})$ after incubation of reaction mixture at $37{ }^{\circ} \mathrm{C}$ for $10 \mathrm{~min}$. One unit $(\mathrm{U} / \mathrm{ml})$ of keratinase activity was defined as an increase in absorbance by 0.001 units at $280 \mathrm{~nm}$ with control $/ \mathrm{min}$.

Enzyme activity $U=4 \times n \times A_{280} /(0.01 \times 10)$

where $n$ is the dilution rate, 4 is the final reaction volume, and 10 is the incubation time (min).

\section{Estimation of soluble protein and released amino acids}

After every $24 \mathrm{~h}$ of incubation, the amount of soluble proteins and amino acids was quantified. Aliquots were withdrawn and centrifuged at 10,000 rpm for $10 \mathrm{~min}$. The supernatant was pooled for the estimation of soluble protein by Folin phenol (Lowry et al. 1951) and amino acid content using and Ninhydrin method (Moore and Stein 1954).

\section{Preparation of inoculum}

Ability of AF-2 isolate with feather-degraded lysate to alleviate salt stress was evaluated by pot trial. Seeds of wheat (T. aestivum L.) were surface sterilized by $70 \%$ ethanol treatment for $1 \mathrm{~min}$ followed by four times washing with sterilized distilled water. Seeds were sown in pots (12 seeds/pot). Each pot was inoculated separately with AF-2 inoculum (AI) and AF-2 with feather lysate inoculum
$(\mathrm{A}+\mathrm{FLI})$ in $5 \mathrm{ml}$ amount. Each set has three replicates. Uninoculated soil was used as control. For imposing salt stress, plants were watered with $100 \mathrm{mM}$ salt solution at $48 \mathrm{~h}$ of intervals. After 15 and 30 days of sowing, the plantlets were uprooted for analysis.

\section{Estimation of chlorophyll}

The fresh leaves of plants were collected randomly after 15 and 30 days of plantation; washed thoroughly and blotted. Then, $0.5 \mathrm{~g}$ of leaf tissue was crushed in $80 \%$ acetone and the final volume was adjusted to $10 \mathrm{ml}$ and stored overnight under refrigeration. This extract was then centrifuged and filtered through glasswool. The absorbance of the supernatant was recorded at 663 and $645 \mathrm{~nm}$ and the total chlorophyll content was determined (Arnon 1949).

\section{Estimation of proline}

Proline content of salt-stressed plants, bacterized saltstressed plant and feather lysate supplemented bacterized salt-stressed plants were estimated according to Bates et al. (1973). Briefly, $0.5 \mathrm{~g}$ fresh leaves was homogenized with $3 \%$ sulfosalicylic acid and immediately centrifuged at $11,500 \mathrm{rpm}$ for $5 \mathrm{~min}$. One $\mathrm{ml}$ of supernatant was taken for analysis. Absorbance was measured at $520 \mathrm{~nm}$ and the calibration curve was determined using L-proline as standard.

\section{Quantification of free proteins and amino acids}

$1 \mathrm{~g}$ of plant material of test and control was crushed in $100 \mathrm{mM}$ phosphate buffer ( $\mathrm{pH} \mathrm{7}$; for protein) and in $80 \%$ ethanol (for amino acids). The formed extracts were centrifuged and supernatant was used for the protein estimation (Lowry et al. 1951) and amino acids estimation (Moore and Stein 1954).

\section{Analysis of total soluble phenol and flavonoids}

Total soluble phenol was estimated using Prussian Blue method modified by Graham (1992). The absorbance of sample was read at $700 \mathrm{~nm}$ using UV-Vis spectrophotometer and expressed in terms of gallic acid equivalents. Total flavonoid content was determined by colorimetric method of aluminum chloride (Kim et al. 2003). Absorbance was measured at $415 \mathrm{~nm}$ and expressed in terms of rutin equivalents.

\section{Estimation of $\mathrm{Na}^{+}$and $\mathrm{K}^{+}$in plant tissue}

After 15 and 30 days of growth, fresh leaf samples of AI and A + FLI treated salt-stressed and non-inoculated 
salinity affected wheat plants were collected and analyzed for sodium $\left(\mathrm{Na}^{+}\right)$and potassium $\left(\mathrm{K}^{+}\right)$concentration by flame photometer as described by Ryan et al. (2007).

\section{Soil analysis}

The total $\mathrm{N}$ content of the soil was determined by Kjeldahl method. Total carbon contents were determined by Tyurin method (Nustorova et al. 2006). In addition, $\mathrm{Mg}, \mathrm{Ca}$ and $\mathrm{P}$ contents were determined by atomic absorption spectrophotometer (Perkin-Elmer analyst, USA). All the analytical techniques were performed according to APHA (1998).

\section{Statistical analysis}

All the results are an average of three or more determinations. Analysis of variance was carried out of all data at $p<0.05$ using Graph Pad software (GraphPadIn Stat version 3.00, GraphPad Software, San Diego, CA, USA).

\section{Results}

\section{Isolation and identification of ACC deaminase producer and its PGPT}

The AF-2 isolate showed growth on minimal medium containing $\mathrm{ACC}$ as a sole source of nitrogen. AF-2 exhibited $10 \pm 0.41\left(\mu \mathrm{mol} \mathrm{mg}{ }^{-1} \mathrm{~h}^{-1}\right)$ of ACC deaminase activity. The AF-2 was tested for range of activities considered as contributory for promoting plant growth. The organism showed positive results for plant hormone, IAA production. The maximum value of IAA production was found to be $61.18 \pm 0.5 \mu \mathrm{g} / \mathrm{ml}$ after $24 \mathrm{~h}$ of incubation; further increase in incubation period decreased the production of IAA. Isolate AF-2 also showed siderophore, ammonia, HCN production and antifungal enzyme production (Protease and cellulase) (Table 2). In addition to PGPT, the AF-2 isolate also showed 2\% salt tolerance. The isolate was identified as C. gleum sp. SUK by $16 \mathrm{~S}$ rDNA sequence analysis. The phylogenic tree of $C$. gleum sp. SUK in relation with Genebank data is illustrated in Fig. 1.

\section{Feather degradation}

The feather degradation ability of isolate AF- 2 was determined in submerged cultivation using minimal medium. Isolate showed degradation of chicken feathers and used it as a carbon, nitrogen and sulfur source for energy production and growth. The maximum keratinase activity of $86 \mathrm{U} / \mathrm{ml}$ was recorded at $96 \mathrm{~h}$ of incubation; further increase in incubation decreased the enzyme activity (Fig. 2). As the degradation of feathers continues, the concentration of soluble proteins was increased. The maximum $3.893 \pm 0.11 \mathrm{mg} / \mathrm{ml}$ of soluble proteins was observed at $96 \mathrm{~h}$ of incubation. The amount of proteins increased equivalently with amino acids up to $96 \mathrm{~h}$; further increase in incubation period decreased the amount of proteins released while concentration of amino acids was increased up to $4.319 \mathrm{mg} / \mathrm{ml}$ at $144 \mathrm{~h}$ (Fig. 3).

\section{Effect of inoculum on T. aestivum L. growth}

Wheat (T. aestivum L.) plants exposed to $100 \mathrm{mM}$ of salt stress for 30 days showed reduced growth as compared to non-stressed control plants. Salinity stress affects shoot length, root length, fresh and dry weights of non-inoculated
Table 2 Plant growth promoting traits of AF-2 isolate

\begin{tabular}{lll}
\hline Sr no. & AF-2 isolate & Activity \\
\hline 1 & ACC deaminase activity & \\
& Qualitative & ++ \\
& Quantitative $\left(\mu \mathrm{mol} \mathrm{mg}^{-1} \mathrm{~h}^{-1}\right)$ & $10 \pm 0.41\left(\mu \mathrm{mol} \mathrm{mg}^{-1} \mathrm{~h}^{-1}\right)$ \\
2 & Phosphate solubilization $(\mu \mathrm{g} / \mathrm{ml})$ & - \\
3 & IAA production $(\mu \mathrm{g} / \mathrm{ml})$ & $61.18 \pm 0.55 \mu \mathrm{g} / \mathrm{ml}$ \\
4 & Siderophore production & ++ \\
5 & Ammonia production & ++ \\
6 & HCN production & ++ \\
7 & Fungal cell wall degrading enzyme production & \\
& Protease & ++ \\
& Chitinase & - \\
& Cellulase & ++
\end{tabular}

Data are shown as mean \pm standard error of three replicates and $p<0.05$ according to Graph Pad software Values in parenthesis show the percent decrease in the growth compared to control + good, ++ very good, - negative 
Fig. 1 Phylogenetic tree of Chryseobacterium gleum sp. SUK and other closely related Chryseobacterium species based on $16 \mathrm{~S}$ rDNA sequences. The tree was generated using neighbor joining method. Bar 0.5 substitution per site

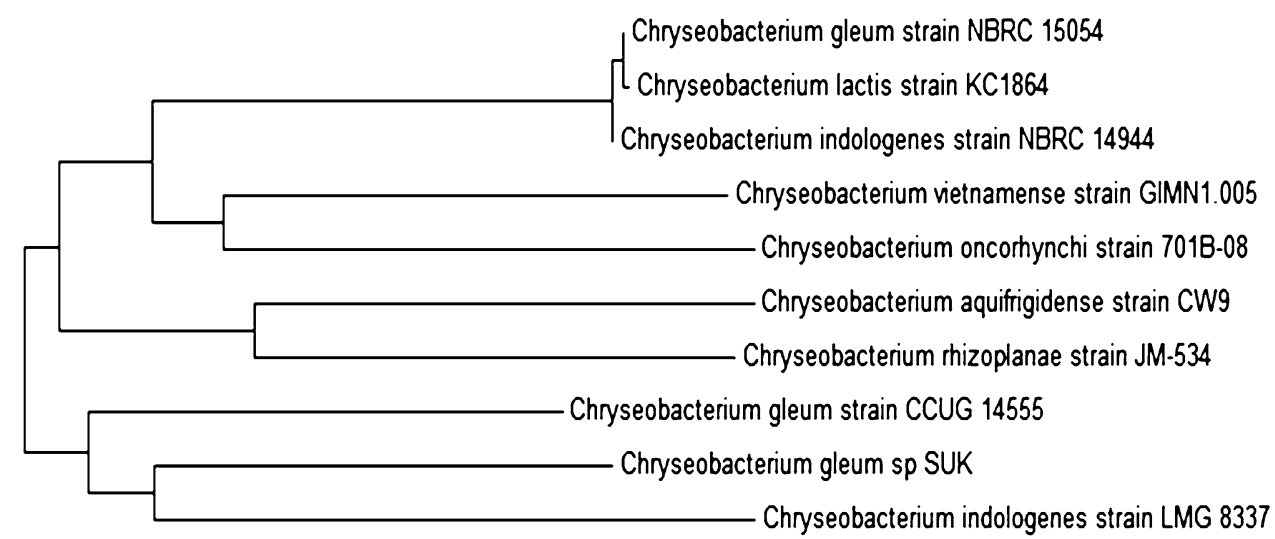

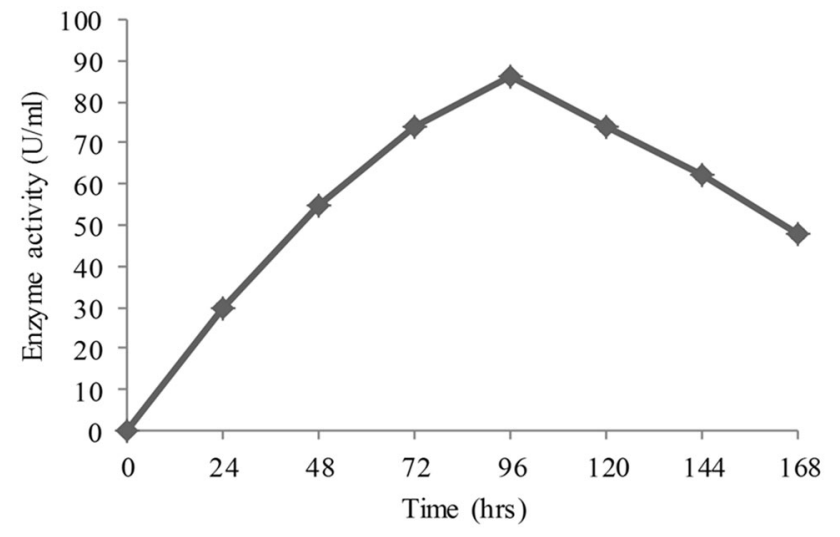

Fig. 2 Keratinase activity of Chryseobacterium gleum sp. SUK after every $24 \mathrm{~h}$ of incubation in minimal medium containing $1 \%$ poultry feather at $30{ }^{\circ} \mathrm{C}$ and $120 \mathrm{rpm}$ (data are presented as the average of three replicates and $p<0.05$ according to Graph Pad software)

stressed plants as compared to salt-stressed plants inoculated separately with AI and A + FLI.

After 15 days, salt-stressed wheat plant showed shoot length of $11.46 \pm 0.37 \mathrm{~cm}$, root length of $4.2 \pm 0.1 \mathrm{~cm}$, fresh weight of $1.89 \pm 0.07 \mathrm{~g}$ and dry weight of $0.16 \pm 0.003 \mathrm{~g}$. A + FLI treated salt-stressed plant showed shoot length of $19 \pm 0.7 \mathrm{~cm}$, root length of $6.3 \pm 0.2 \mathrm{~cm}$, fresh weight of $2.92 \pm 0.02 \mathrm{~g}$ and dry weight of $0.21 \pm 0.002 \mathrm{~g}$ while AI showed $17.53 \pm 0.2 \mathrm{~cm}$ shoot length, $5.5 \pm 0.17 \mathrm{~cm}$ root length, $1.96 \pm 0.02 \mathrm{~g}$ fresh weight and $0.18 \pm 0.003 \mathrm{~g}$ dry weight under salt-stressed conditions.

After 30 days of growth, the $100 \mathrm{mM}$ salt-stressed wheat plant showed a shoot length of $19.5 \pm 0.17 \mathrm{~cm}$, root length of $6 \pm 0.1 \mathrm{~cm}$, fresh weight of $2.65 \pm 0.16 \mathrm{~g}$ and dry weight of $0.25 \pm 0.003 \mathrm{~g}$. However, salt-stressed plant inoculated with A + FLI showed $29.2 \pm 0.3 \mathrm{~cm}$ shoot length, $11.5 \pm 0.3 \mathrm{~cm}$ root length, $3.84 \pm 0.02 \mathrm{~g}$ fresh weight and $0.35 \pm 0.003 \mathrm{~g}$ dry weight. While AI showed shoot length of $25.46 \pm 0.11 \mathrm{~cm}$, root length of

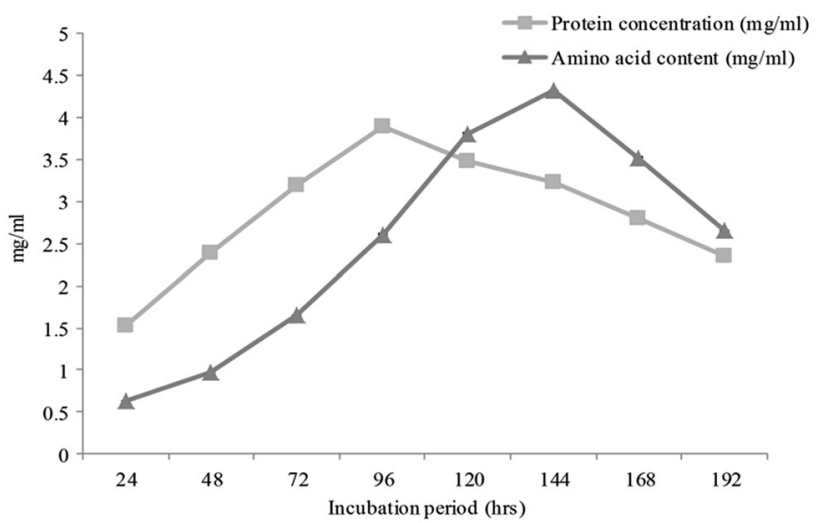

Fig. 3 Proteins and amino acids contents of Chryseobacterium gleum sp. SUK inoculated minimal medium containing $1 \%$ poultry feather at $30{ }^{\circ} \mathrm{C}$ and $120 \mathrm{rpm}$ after every $24 \mathrm{~h}$ of incubation (data are presented as the average of three replicates and $p<0.05$ according to Graph Pad software)

$9.6 \pm 0.43 \mathrm{~cm}$, fresh weight of $3.04 \pm 0.02 \mathrm{~g}$ and dry weight of $0.31 \pm 0.003 \mathrm{~g}$ under identical conditions. Figures 4 and 5 show that inoculation of salinity-stressed wheat plants with A + FLI reduced the detrimental effects of salinity stress that indicates superior performance of A + FLI for enhancing growth of wheat plant in presence of salt stressor.

\section{Effect of inoculum on photosynthetic pigment and proline content of $T$. aestivum $\mathrm{L}$.}

Under stress condition, photosynthetic pigment was maximum in the leaves of the plant treated with A + FLI $\left(18.50 \pm 0.11\right.$ and $22.53 \pm 0.09 \mathrm{mg} \mathrm{g}^{-1}$ dry weight) followed AI inoculum $\left(15.65 \pm 0.10\right.$ and $16.50 \pm 0.24 \mathrm{mg} \mathrm{g}^{-1}$ dry weight) over salinity-stressed control plant (10.66 \pm 0.30 and $14.43 \pm 0.31 \mathrm{mg} \mathrm{g}^{-1}$ dry weight) after 15 and 30 days, respectively (Fig. 6). Under salt stressor, wheat plant 


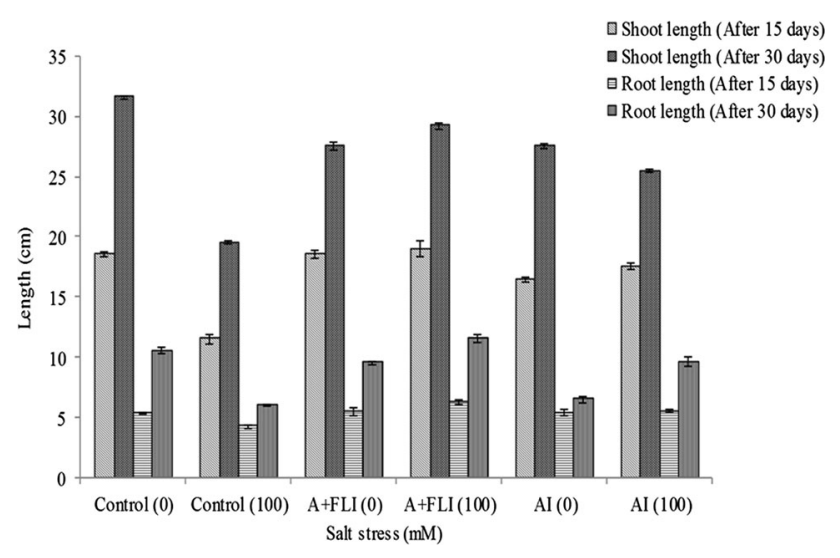

Fig. 4 Effect of A + FLI and AI on shoot and root length of Triticum aestivum $\mathrm{L}$. in the presence and absence of salt stressor after 15 and 30 days of growth. Control $(0)$ soil with no salinity stress, Control (100) soil with $100 \mathrm{mM}$ salinity stress, $A+F L I(0)$ $\mathrm{A}+\mathrm{FLI}+$ soil with no salinity stress, $A+F L I(100) \mathrm{A}+\mathrm{FLI}+$ soil with $100 \mathrm{mM}$ salinity stress, $A I(0) \mathrm{AI}+$ soil with no salinity stress, $A I(100) \mathrm{AI}+$ soil with $100 \mathrm{mM}$ salinity stress (data are presented as the average of three replicates and $p<0.05$ according to Graph Pad software)

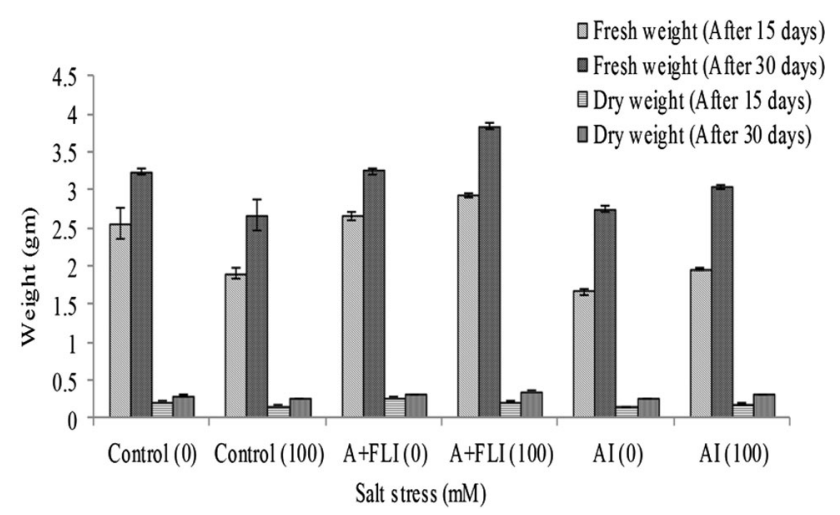

Fig. 5 Effect of A + FLI and AI on fresh and dry weight of Triticum aestivum L. in the presence and absence of salt stressor after 15 and 30 days of growth. Control (0) soil with no salinity stress, Control (100) soil with $100 \mathrm{mM}$ salinity stress, $A+F L I(0) \mathrm{A}+\mathrm{FLI}+$ soil with no salinity stress, $A+F L I(100) \mathrm{A}+\mathrm{FLI}+$ soil with $100 \mathrm{mM}$ salinity stress, $A I(0)$ AI + soil with no salinity stress, $A I(100)$ $\mathrm{AI}+$ soil with $100 \mathrm{mM}$ salinity stress (data are presented as the average of three replicates and $p<0.05$ according to Graph Pad software)

synthesizes proline to a great extent as compared to nonstressed plant. Inoculation of salt-affected plant with the $\mathrm{A}+\mathrm{FLI}$ and AI causes reduction in proline content. Wheat crops subjected to salinity showed $2.47 \pm 0.06$ and $3.16 \pm 0.05 \mu \mathrm{mol} \mathrm{g}^{-1}$ dry weight of proline. However, saltstressed plant with A + FLI showed $1.76 \pm 0.02$ and $2.25 \pm 0.15 \mu \mathrm{mol} \mathrm{g}^{-1}$ dry weight, while AI showed $1.77 \pm 0.05$ and $2.26 \pm 0.04 \mu \mathrm{mol} \mathrm{g}^{-1}$ dry weight of proline after 15 and 30 days, respectively (Fig. 7).

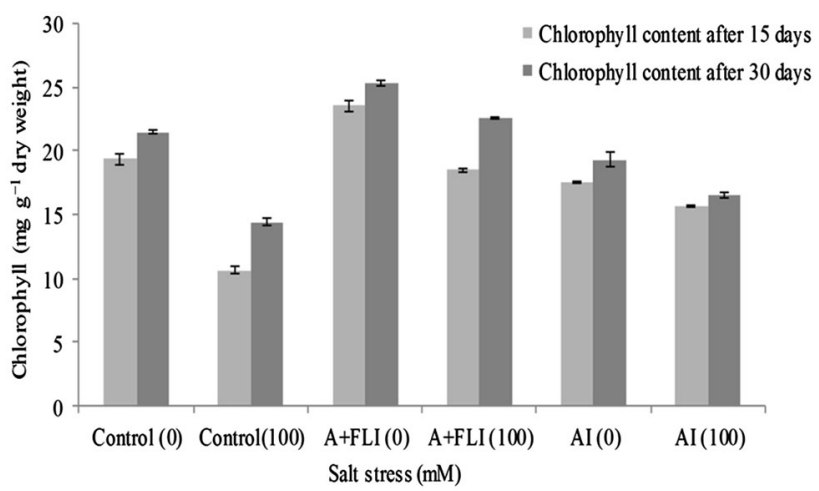

Fig. 6 Effect of A + FLI and AI on chlorophyll contents of Triticum aestivum L. in presence and absence of salt stressor after 15 and 30 days of growth. Control (0) soil with no salinity stress, Control (100) soil with $100 \mathrm{mM}$ salinity stress, $A+F L I(0) \mathrm{A}+\mathrm{FLI}+$ soil with no salinity stress, $A+F L I(100) \mathrm{A}+\mathrm{FLI}+$ soil with $100 \mathrm{mM}$ salinity stress, $A I(0)$ AI + soil with no salinity stress, $A I(100)$ $\mathrm{AI}+$ soil with $100 \mathrm{mM}$ salinity stress (data are presented as the average of three replicates and $p<0.05$ according to Graph Pad software)

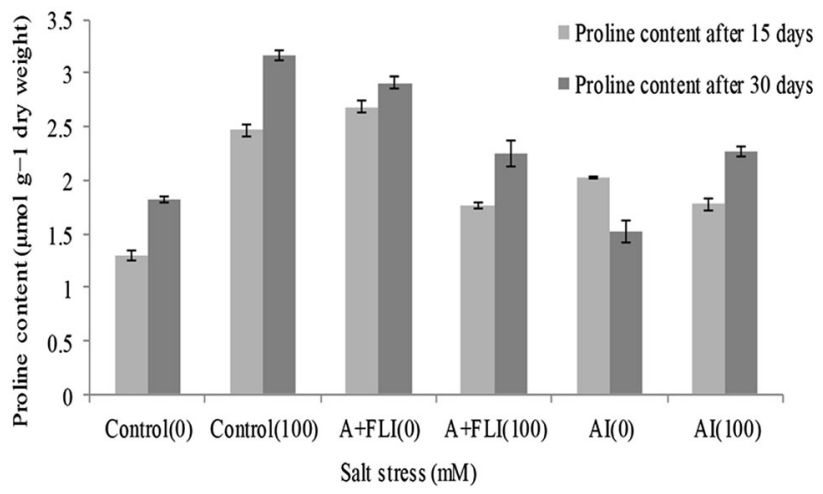

Fig. 7 Effect of A + FLI and AI on proline contents of Triticum aestivum L. in the presence and absence of salt stressor after 15 and 30 days of growth. Control (0) soil with no salinity stress, Control (100) soil with $100 \mathrm{mM}$ salinity stress, $A+F L I(0) \mathrm{A}+\mathrm{FLI}+$ soil with no salinity stress, $A+F L I(100) \mathrm{A}+\mathrm{FLI}+$ soil with $100 \mathrm{mM}$ salinity stress, $A I(0)$ AI + soil with no salinity stress, $A I(100)$ $\mathrm{AI}+$ soil with $100 \mathrm{mM}$ salinity stress (data are presented as the average of three replicates and $p<0.05$ according to Graph Pad software)

\section{Effect of inoculum on proteins and amino acids content of $T$. aestivum $\mathrm{L}$.}

Total protein content was found to be maximum in A + FLI supplemented salt-stressed plant leaves $(2.13 \pm 0.15$ and $2.48 \pm \pm 0.19 \mathrm{mg} \mathrm{g}^{-1}$ dry weight) as compared to saltstressed control plant $\left(1.43 \pm 0.05\right.$ and $1.76 \pm 0.1 \mathrm{mg} \mathrm{g}^{-1}$ dry weight) after 15 and 30 days. Furthermore, A + FLI was also effective in enhancing the level of amino acids in saltstressed plant $\left(1.19 \pm 0.04\right.$ and $1.65 \pm 0.01 \mathrm{mg} \mathrm{g}^{-1}$ dry weight) after 15 and 30 days compared to non-inoculated 


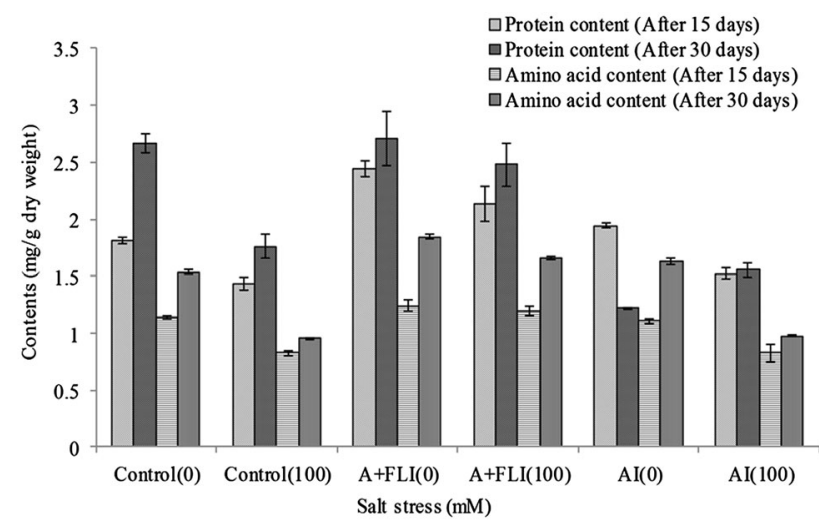

Fig. 8 Effect of A + FLI and AI on proteins and amino acids content of Triticum aestivum L. in the presence and absence of salt stressor after 15 and 30 days of growth. Control $(0)$ soil with no salinity stress, Control (100) soil with $100 \mathrm{mM}$ salinity stress, $A+F L I(0)$ $\mathrm{A}+\mathrm{FLI}+$ soil with no salinity stress, $A+F L I(100) \mathrm{A}+\mathrm{FLI}+$ soil with $100 \mathrm{mM}$ salinity stress, $A I(0) \mathrm{AI}+$ soil with no salinity stress, $A I(100) \mathrm{AI}+$ soil with $100 \mathrm{mM}$ salinity stress (data are presented as the average of three replicates and $p<0.05$ according to Graph Pad software)

salinity-stressed wheat plant, while AI showed $1.52 \pm 0.04$ and $1.55 \pm 0.05 \mathrm{mg} \mathrm{g}^{-1}$ dry weight of proteins and $0.82 \pm 0.008$ and $0.97 \pm 0.003 \mathrm{mg} \mathrm{g}^{-1}$ dry weight of amino acids in salt-stressed plant after 15 and 30 days, respectively (Fig. 8).

\section{Effect of inoculum on total soluble phenol and flavonoids content of T. aestivum $\mathrm{L}$.}

In response to salinity stress, changes in polyphenol contents of wheat plants were observed after 15 and 30 days of growth when added with the studied inoculum. Wheat plant showed increase in amount of polyphenol content with increasing concentration of salt stressor. Wheat plants subjected to $100 \mathrm{mM}$ of salt stress showed increase in amount of polyphenol content when inoculated with A + FLI followed by stressed plant with AI. Inoculation of wheat plant with A + FLI exhibited $9.14 \pm 0.46$, wheat plant with AI showed $8.76 \pm 0.82$, while the salt-stressed plant exhibited $8.13 \pm 0.27 \mathrm{mg} / \mathrm{g}$ dry weight of total soluble phenol after 15 days. Salt-stressed wheat plant with A + FLI showed $10.32 \pm 0.61$, salt stress plants with AI showed $9.06 \pm 0.16$ and salt stress non-inoculated plant showed $8.49 \pm 0.10 \mathrm{mg} / \mathrm{g}$ dry weight of total soluble phenol after 30 days (Fig. 9).

Our finding indicated the difference in total flavonoids content in salt-stressed and salt-stressed inoculated plants. As the salt stress increases from 0 to $100 \mathrm{mM}$, the amount of total flavonoids was also found to be increased. Inoculation of wheat plants with AI and A + FLI in salt stress of $100 \mathrm{mM}$ showed difference in total flavonoid content

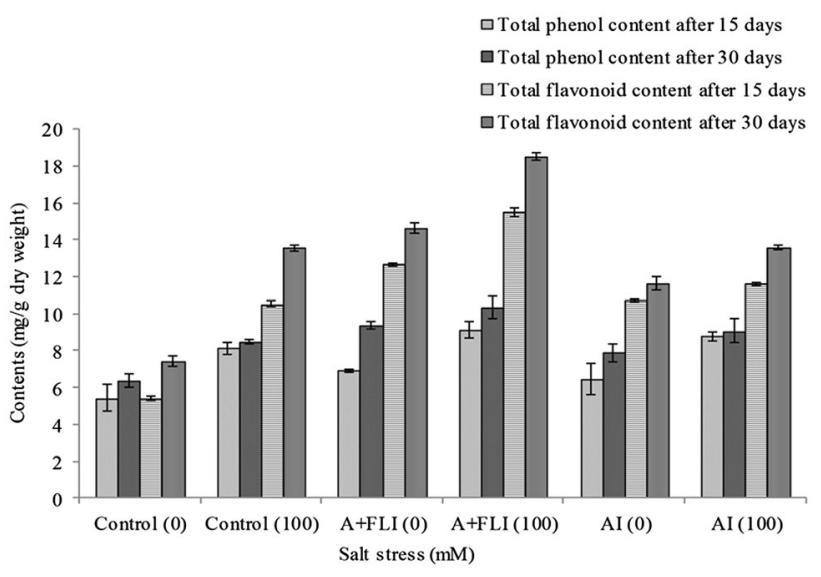

Fig. 9 Effect of A + FLI and AI on total soluble phenol and flavonoid contents of Triticum aestivum $\mathrm{L}$. in the presence and absence of salt stressor after 15 and 30 days of growth. Control $(0)$ soil with no salinity stress, Control (100) soil with $100 \mathrm{mM}$ salinity stress, $A+F L I(0)$ A + FLI + soil with no salinity stress, $A+F L I(100) \mathrm{A}+\mathrm{FLI}+$ soil with $100 \mathrm{mM}$ salinity stress, $A I(0)$ $\mathrm{AI}+$ soil with no salinity stress, $A I(100) \mathrm{AI}+$ soil with $100 \mathrm{mM}$ salinity stress (data are presented as the average of three replicates and $p<0.05$ according to Graph Pad software)

(Fig. 9). After 15 days, salt-stressed plants showed $10.53 \pm 0.15$, salt-stressed plants with A + FLI showed $15.5 \pm 0.24$ and salt-stressed plants with AI showed $11.59 \pm 0.12 \mathrm{mg} / \mathrm{g}$ dry weight of flavonoids. In case of 30 days, salt-stressed plants showed $13.55 \pm 0.14$, saltstressed plants with A + FLI showed $18.50 \pm 0.21$, while salt-stressed plants with AI showed $13.57 \pm 012 \mathrm{mg} / \mathrm{g}$ dry weight of flavonoids.

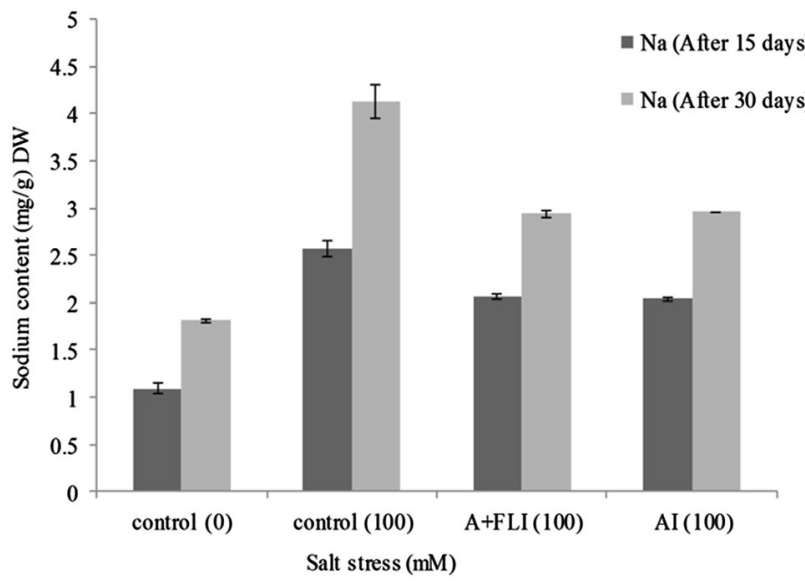

Fig. 10 Effect of A + FLI and AI on $\mathrm{Na}^{+}$contents of Triticum aestivum $\mathrm{L}$. in the presence of salt stressor after 15 and 30 days of growth. Control (0) soil with no salinity stress, Control (100) soil with $100 \mathrm{mM}$ salinity stress, A + FLI(100) A + FLI + soil with $100 \mathrm{mM}$ salinity stress, $A I(100)$ AI + soil with $100 \mathrm{mM}$ salinity stress (data are presented as the average of three replicates and $p<0.05$ according to Graph Pad software) 
Plants inoculated with A + FLI showed increase in total flavonoids and total soluble phenol in the presence of $100 \mathrm{mM}$ salt stressor as compared to salt-stressed uninoculated control plants after 15 and 30 days, respectively (Fig. 9).

\section{Effect of inoculum on $\mathrm{Na}^{+}$and $\mathrm{K}^{+}$uptake by $T$. aestivum $\mathbf{L}$.}

Wheat plants exposed to $100 \mathrm{mM}$ of salt stressor concentration exhibited an increased $\mathrm{Na}^{+}$and decreased $\mathrm{K}^{+}$ content in shoot (Figs. 10, 11). However, wheat plants supplemented with $\mathrm{A}+$ FLI caused a decline in $\mathrm{Na}^{+}$ content in shoot by $28.87 \%$ and increase in $\mathrm{K}^{+}$uptake by $12.95 \%$ in the presence of $100 \mathrm{mM}$ of salinity compared with plants growing in non-inoculated salt stressor environment. Wheat plants having $100 \mathrm{mM}$ salt stress when inoculated with AI caused decrease in $\mathrm{Na}^{+}$content in shoot by $28.38 \%$ as compared to control and increase in the $\mathrm{K}^{+}$ uptake in shoot by $12.59 \%$.

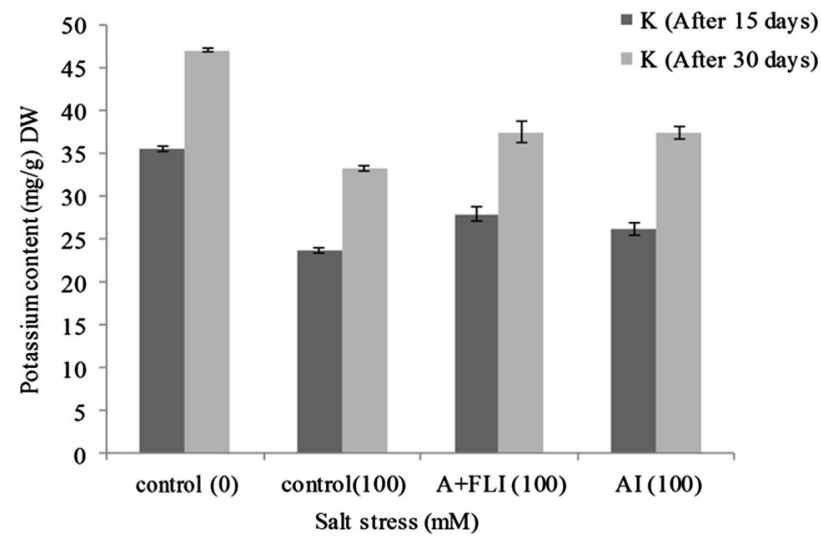

Fig. 11 Effect of $\mathrm{A}+\mathrm{FLI}$ and $\mathrm{AI}$ on $\mathrm{K}^{+}$contents of Triticum aestivum $\mathrm{L}$. in the presence of salt stressor after 15 and 30 days of growth. Control (0) soil with no salinity stress, Control (100) soil with $100 \mathrm{mM}$ salinity stress, $A+F L I(100) \mathrm{A}+\mathrm{FLI}+$ soil with $100 \mathrm{mM}$ salinity stress, $A I(100) \mathrm{AI}+$ soil with $100 \mathrm{mM}$ salinity stress (data are presented as the average of three replicates and $p<0.05$ according to Graph Pad software)

\section{Soil analysis}

Soil analysis was done to study the effect of A + FLI on soil constituents. Different samples were used for soil analysis, namely control soil (without salt stress), $100 \mathrm{mM}$ salt-stressed control soil, $100 \mathrm{mM}$ salt-stressed soil with A + FLI, soil with A + FLI and $100 \mathrm{mM}$ salt-stressed soil with AI. The concentrations of major and minor nutrients like $\mathrm{N}, \mathrm{P}, \mathrm{C}, \mathrm{Mg}$ and $\mathrm{Ca}$ are altered significantly under saline stress after the addition of A + FLI (Table 3).

\section{Discussion}

In the present work, we have isolated ACC deaminase producing isolate from soil sample and characterized its PGPT, feather degradation activity and salt tolerance character to formulate a complete bioformulation for saltstressed soil. The isolate AF-2 was identified as C. gleum sp. SUK as per the biochemical properties and 16S rDNA gene sequences. There are few reports on the role of degraded feather lysate to promote plant growth as they are rich source of nitrogen (Bhange et al. 2016; Kim et al. 2001). Although the Chryseobacterium genus is known to have strong keratinase activity (Riffel et al. 2007; Wang et al. 2008); however, this is the first report on salinity stress amelioration using the combination of ACC deaminase producing organism with feather-degraded lysate.

Effect of A + FLI was studied on wheat crops under salt stress in pot trials. Irrigation with salt solution retarded the length of root and shoot of wheat plants under noninoculated soil and as the level of stress increases the effects became even more adverse. However, plants inoculated with A + FLI exhibited higher root and shoot length, fresh and dry weight by dropping the deleterious effects of salinity. In case of shoot length, A + FLI had $49 \%$ improvement over salt-stressed non-inoculated plants, while salt-affected wheat plants supplemented with A + FLI showed $92.22 \%$ increase in root length in the presence of $100 \mathrm{mM}$ salinity stress after 30 days (Fig. 4). This may be due to the ACC deaminase production by the

Table 3 Soil analysis

\begin{tabular}{|c|c|c|c|c|c|c|c|}
\hline Sr no. & Sample & Total C (\%) & Total N (\%) & $\mathrm{Mg}(\mathrm{ppm})$ & $\mathrm{Ca}(\mathrm{ppm})$ & $\mathrm{PO}_{4}(\mathrm{ppm})$ & $\mathrm{C} / \mathrm{N}$ ratio \\
\hline 1 & Control & $0.48 \pm 0.11$ & $0.105 \pm 0.37$ & $312.5 \pm 1.2$ & $392.8 \pm 2.1$ & $830.1 \pm 0.021$ & 4.5714 \\
\hline 2 & Control (100 mM salt stress) & $0.39 \pm 0.71$ & $0.092 \pm 0.07$ & $286.5 \pm 0.2$ & $371.4 \pm 2.1$ & $712.7 \pm 0.012$ & 4.2391 \\
\hline 3 & $\mathrm{~A}+\mathrm{FLI}$ & $1.01 \pm 0.21$ & $0.163 \pm 0.01$ & $336.2 \pm 2.5$ & $413.1 \pm 5.7$ & $970.4 \pm 0.025$ & 6.1963 \\
\hline 4 & A + FLI (100 mM salt stress) & $1.03 \pm 0.31$ & $0.159 \pm 0.43$ & $341.2 \pm 1.3$ & $411.4 \pm 3.6$ & $958 \pm 0.04$ & 6.4779 \\
\hline 5 & AI (100 mM salt stress) & $0.63 \pm 0.01$ & $0.123 \pm 0.76$ & $337.4 \pm 1.5$ & $403.1 \pm 4.6$ & $748.8 \pm 0.83$ & 5.1219 \\
\hline
\end{tabular}

Data are shown as mean \pm standard error of three replicates and $p<0.05$ according to Graph Pad software 
isolate which decreases the level of stress hormone ethylene (Ahmad et al. 2011). These results are in accordance with Saravanakumar and Samiyappan (2007) who reported an increase in total yield of groundnuts in salinity by inoculation of Pseudomonas strain having ability to produce ACC deaminase. In the present study, the inoculation of plant with A + FLI improved fresh and dry weight by 44.72 and $41.86 \%$ (Fig. 5). Studies have reported that the plant growth promoting bacterial inoculation to the crops increases the fresh and dry weight of the root system (Yuan et al. 2013). Similarly, Bhange et al. (2016) reported an increase in root length and root and shoot weight of Vigna radiata $\mathrm{L}$. due to the addition of feather-degraded lysate with the degrading isolate Bacillus subtilis PF1. Results showed the effects of both the inoculum on the vegetative parameters which indicate that the ACC deaminase activity of isolate reduces the salinity stress while the biostimulants present in bioformulation significantly improved the growth of plant.

The isolate SUK showed positive results for IAA, siderophore, ammonia and $\mathrm{HCN}$ production as well as for protease and cellulase (Table 2). PGPB promote the plant growth directly by producing indole acetic acid, a plant hormone playing a consequential role in division of cells and elongation (Patten and Glick 2002). The C. gleum sp. SUK has the ability to produce $61.18 \pm 0.5 \mu \mathrm{g} / \mathrm{ml}$ IAA after $24 \mathrm{~h}$ of incubation in the presence of $0.2 \%$ of tryptophan. Keratin is the rich source of tryptophan (Tsavkelova et al. 2012); hence, the feather-degraded lysate may serve as a source of tryptophan which can be converted to IAA with strain SUK. Indirectly, PGPB promote the plant growth by controlling fungal pathogen through hydrolytic enzyme production and siderophore synthesis that causes competition for iron (Compant et al. 2005) and ammonia production which is also one of the biocontrol agents (Trivedi et al. 2008). Similarly, HCN also indirectly supports the plant growth by playing the role of microbial antagonist (Goswami et al. 2014). PGPB play an important role to raise the nutritional status of soil and providing nutrition to plant for its better growth.

Salinity stress causes reduction in photosynthetic pigment (Saha et al. 2010), but salt stress plants provided with A + FLI showed increased chlorophyll content. According to Neales (1956), synthesis of photosynthetic pigment depends on the availability of $\mathrm{N}, \mathrm{Mg}, \mathrm{S}, \mathrm{Ca}, \mathrm{Fe}, \mathrm{Mn}$ and $\mathrm{Zn}$ to the plants. These metals are present in the studied inoculum which might be responsible for the increased chlorophyll content of plants as compared to the chlorophyll contents in only isolate supplemented stressed plant (Fig. 6). In the presence of salt stressor, the wheat crop produces increased level of proline however; the inoculation of wheat crops with A + FLI in the presence of salt stress decreased the proline concentration. These results are in accordance with Nadeem et al. (2007) who found that the plant proline contents are increased by saline stress, but decreased by inoculation with PGPB. However, in the absence of salt stressor the supplemented inoculum increases the proline contents of crops (Fig. 7). There are some reports which suggest that under non-stressed conditions accumulation of proline occurs for the development of plants acting as signal molecule and involved mainly in flowering process (Mattioli et al. 2009).

Wheat plants supplemented with A + FLI exhibited maximum protein contents of $2.48 \mathrm{mg} / \mathrm{g}$ dry weight and amino acid $1.655 \mathrm{mg} / \mathrm{g}$ dry weight in the presence of salt stress of $100 \mathrm{mM}$ after 30 days (Fig. 8). This result is corroborated by Gurav and Jadhav (2013), who reported increase in proteins and amino acid contents of banana plants by the supplementation of feather-degraded lysate as bioenhancer. The feather-degraded lysate consists of keratin protein-degraded products (peptides and amino acids) which plays an important role in plant growth and developments (Cao et al. 2012).

Synthesis of polyphenol is one of the mechanisms used by the plant to prevent oxidative damage (Hichem and Mounir 2009). In this study, wheat crops exposed to salt stressor of $100 \mathrm{mM}$ produce increased level of polyphenol; however, salt-stressed wheat crops when added with A + FLI improved the polyphenol level which indicates the superior performance of isolate to decrease the salt stress. McGrath et al. (1994) also reported that the inoculation of crops with organic waste accumulates the antioxidants. The presence of feather-degraded lysate in bioformulation is also contributed for increase in polyphenol content of wheat crops exposed to salinity (Fig. 9).

Flavonoid contents of plants depend on many factors including biotic and abiotic stresses, environment and genetic factors (Pandino et al. 2009). In this study, wheat crops in saline condition without inoculation exhibit increased level of flavonoids but decreased growth furthermore; salinity-stressed crops when integrated with A + FLI also showed an improved level of flavonoids and improvement in crops growth (Fig. 9). Under salinity stress, wheat crops inoculated with studied bioformulation produce an increased level of flavonoid; it protects the wheat crops against reactive oxygen species produced in stress conditions (Sreenivasulu et al. 2000).

In this study, uninoculated wheat crops exposed to salinity stress showed increase in $\mathrm{Na}^{+}$and decrease in $\mathrm{K}^{+}$ content. However, salt-stressed crops supplemented with $\mathrm{A}+$ FLI favor the $\mathrm{K}^{+} / \mathrm{Na}^{+}$ratio by decreasing $\mathrm{Na}^{+}$and increasing $\mathrm{K}^{+}$contents of wheat crops. Figures 10 and 11 indicate the additional feature of bioformulation to reduce the salt stress in plant. These results are in accordance with (Nadeem et al. 2013). The particular mechanism of such 
nutrient uptake regulation by the bacteria is not clear; it may be due to the beneficial effect of PGPT of bacteria which results in improved root growth that causes increase in the surface area, resulting in better nutrient uptake from soil. Also, it may be due to exopolysaccharide that binds to $\mathrm{Na}^{+}$and decreases its availability for plant uptake (Ashraf et al. 2004).

Results of soil analysis showed changes in major and minor nutrient in the soil like $\mathrm{N}, \mathrm{P}, \mathrm{C}, \mathrm{Mg}$ and $\mathrm{Ca}$ after inoculation of $\mathrm{A}+\mathrm{FLI}$ in salinity-stressed soil as compared to non-inoculated stressed soil (Table 3). Notably, the inoculum leads to significant changes in carbon and nitrogen content of soil as well as $\mathrm{C} / \mathrm{N}$ ratio that indicates improved soil fertility (Nustorova et al. 2006).

The presence of anions and cations in feather-degraded lysate is responsible for its buffering capacity which has been earlier reported to maintain soil pH (Barrow 1960). The presence of such organic matter in soil modifies the water holding capacity of soil (Haynes and Naidu 1998), increases fertility of soil, germination of seeds and growth of crops (Demissie et al. 2013). Application of featherdegraded lysate as a fertilizer to the saline soil is adventitious due to the presence of high nitrogen level plus; it will prevent the problems associated with solid waste management. In India, agriculture is the major revenue source and farmers are facing difficulties due to extortionate utilization of chemicals and salinity stress which decrement the overall crop yield. Now, it is essential to develop cost efficacious bioinoculants that will protect the plants against stress as well as provide biostimulants to plants, helping them to grow better. The agricultural loss can be obviated by such cost efficacious bioformulation and can additionally be purchased by farmers as compared to high priced chemical fertilizers. According to Hadas and Kautsky (1994), feather-degraded lysate can be utilized as slow release nitrogen fertilizer in soil. However, the process has a disadvantage of less availability of the nitrogen of protein to plants because the feathers are not facilely degraded by most of the proteolytic enzymes. We have exploited novel isolate $C$. gleum sp. SUK that has the facility to degrade poultry feathers into peptides and amino acids and also showed PGPT.

\section{Conclusion}

The studied inoculum constitutes a promising approach to reduce soil salinity stress and waste disposal quandary. The presence of ACC deaminase activity reduces salinity stress and the presence of feather-degraded lysate acts as a bioenhancer. Basically, our finding focuses on inoculation of isolate that could be able to reduce salinity stress by amalgamation of plant growth promoting activities such as IAA synthesis and ACC deaminase activity to reduce stress ethylene level. In additament presence of siderophore, ammonia, HCN production and cellulase, protease activity will indirectly promote the plant growth. The present results confirms amelioration of salinity stress on growth parameters of T. aestivum L. in the presence of $100 \mathrm{mM}$ of salt stressor inoculated with novel cost efficacious bioformulation A + FLI containing $C$. gleum sp. SUK plus feather-degraded lysate. Hence, the use of multifarious plant growth promoting bacteria with feather-degraded lysate and salt tolerance properties hold a great potential to be used as biofertilizer for saline soils.

Acknowledgements Prashant K. Bhagwat is thankful to UGC, India for awarding BSR meritorious Fellowship for doctoral research. Corresponding author wishes to thank UGC-MRP with sanction Grant No. F. No. 41-1282/2012(SR).

\section{Compliance with ethical standards}

Conflict of interest The authors declare that they have no conflict of interest.

\section{References}

Ahmad M, Zahir ZA, Asghar HN, Asghar M (2011) Inducing salt tolerance in mung bean through coinoculation with rhizobia and plant-growth-promoting rhizobacteria containing 1-aminocyclopropane-1-carboxylate deaminase. Can J Microbiol 57(7):578-589

American Public Health Association (1998) APHA. 1998. Standard methods for the examination of water and wastewater, $\mathrm{p} 20$

Arnon DI (1949) Copper enzymes in isolated chloroplasts. Polyphenol oxidase in Beta vulgaris. Plant Physiol 24(1):1

Ashraf M, Hasnain S, Berge O, Mahmood T (2004) Inoculating wheat seedlings with exopolysaccharide-producing bacteria restricts sodium uptake and stimulates plant growth under salt stress. Biol Fertil Soils 40(3):157-162

Babalola OO (2010) Beneficial bacteria of agricultural importance. Biotech Lett 32(11):1559-1570

Barrow NJ (1960) A comparison of the mineralization of nitrogen and of sulphur from decomposing organic materials. Crop Pasture Sci 11(6):960-969

Bates LS, Waldren RP, Teare ID (1973) Rapid determination of free proline for water-stress studies. Plant Soil 39(1):205-207

Bhange K, Chaturvedi V, Bhatt R (2016) Ameliorating effects of chicken feathers in plant growth promotion activity by a keratinolytic strain of Bacillus subtilis PF1. Bioresour Bioprocess 3(1): 13

Cao ZJ, Lu D, Luo LS, Deng YX, Bian YG, Zhang XQ, Zhou MH (2012) Composition analysis and application of degradation products of whole feathers through a large scale of fermentation. Environ Sci Pollut Res 19(7):2690-2696

Chang WT, Hsieh CH, Hsieh HS, Chen C (2009) Conversion of crude chitosan to an anti-fungal protease by Bacillus cereus. World $\mathrm{J}$ Microbiol Biotechnol 25(3):375-382

Compant S, Duffy B, Nowak J, Clément C, Barka EA (2005) Use of plant growth-promoting bacteria for biocontrol of plant diseases: principles, mechanisms of action, and future prospects. Appl Environ Microbiol 71(9):4951-4959 
Demissie S, Muleta D, Berecha G (2013) Effect of phosphate solubilizing bacteria on seed germination and seedling growth of faba bean (Vicia faba L.). Int J Agric Res 8:123-136

Dworkin M, Foster JW (1958) Experiments with some microorganisms which utilize ethane and hydrogen. J Bacteriol 75(5):592

El-Hamshary OIM, Salem HH, Soliman NA (2008) Molecular screening of chitinase gene in Bacillus spp. J Appl Sci Res 4:1118-1123

Fiske CH, Subbarow Y (1925) The colorimetric determination of phosphorus. J Biol Chem 66(2):375-400

Gordon SA, Weber RP (1951) Colorimetric estimation of indole acetic acid. Plant Physiol 26(1):192

Goswami D, Dhandhukia P, Patel P, Thakker JN (2014) Screening of PGPR from saline desert of Kutch: growth promotion in Arachis hypogea by Bacillus licheniformis A2. Microbiol Res 169(1):66-75

Graham HN (1992) Green tea composition, consumption, and polyphenol chemistry. Prev Med 21(3):334-350

Gurav RG, Jadhav JP (2013) A novel source of biofertilizer from feather biomass for banana cultivation. Environ Sci Pollut Res 20(7):4532-4539

Hadas A, Kautsky L (1994) Feather meal, a semi-slow-release nitrogen fertilizer for organic farming. Fertil Res 38(2):165-170

Haynes RJ, Naidu R (1998) Influence of lime, fertilizer and manure applications on soil organic matter content and soil physical conditions: a review. Nutr Cycl Agroecosyst 51(2):123-137

Hichem H, Mounir D (2009) Differential responses of two maize (Zea mays L.) varieties to salt stress: changes on polyphenols composition of foliage and oxidative damages. Ind Crops Prod 30(1):144-151

Honma M, Shimomura T (1978) Metabolism of 1-aminocyclopropane-1-carboxylic acid. Agric Biol Chem 42(10):1825-1831

Hossain MS, Azad AK, Sayem SA, Mostafa G, Hoq MM (2007) Production and partial characterization of feather-degrading keratinolytic serine protease from Bacillus licheniformis MZK-3. J Biol Sci 7(4):599-606

$\mathrm{Hu}$ Y, Schmidhalter U (2005) Drought and salinity: a comparison of their effects on mineral nutrition of plants. J Plant Nutr Soil Sci 168(4):541-549

Kasana RC, Salwan R, Dhar H, Dutt S, Gulati A (2008) A rapid and easy method for the detection of microbial cellulases on agar plates using Gram's iodine. Curr Microbiol 57(5):503-507

Kim JM, Lim WJ, Suh HJ (2001) Feather-degrading Bacillus species from poultry waste. Process Biochem 37(3):287-291

Kim DO, Jeong SW, Lee CY (2003) Antioxidant capacity of phenolic phytochemicals from various cultivars of plums. Food Chem 81(3):321-326

King EO, Ward MK, Raney DE (1954) Two simple media for the demonstration of pyocyanin and fluorescin. J Lab Clin Med 44(2):301-307

Lasekan A, Bakar FA, Hashim D (2013) Potential of chicken byproducts as sources of useful biological resources. Waste Manage 33(3):552-565

Lorck H (1948) Production of hydrocyanic acid by bacteria. Physiol Plant 1(2):142-146

Lowry OH, Rosebrough NJ, Farr AL, Randall RJ (1951) Protein measurement with the Folin phenol reagent. J biolChem 193(1):265-275

Lucy M, Reed E, Glick BR (2004) Applications of free living plant growth-promoting rhizobacteria. Antonie Van Leeuwenhoek 86(1): $1-25$

Marques AP, Pires C, Moreira H, Rangel AO, Castro PM (2010) Assessment of the plant growth promotion abilities of six bacterial isolates using Zea mays as indicator plant. Soil Biol Biochem 42(8):1229-1235
Mattioli R, Costantino P, Trovato M (2009) Proline accumulation in plants: not only stress. Plant Signal Behav 4(11):1016-1018

Mayak S, Tirosh T, Glick BR (2004) Plant growth-promoting bacteria confer resistance in tomato plants to salt stress. Plant Physiol Biochem 42(6):565-572

McGrath SP, Chang AC, Page AL, Witter E (1994) Land application of sewage sludge: scientific perspectives of heavy metal loading limits in Europe and the United States. Environ Rev 2(1):108-118

Moore S, Stein WH (1954) A modified ninhydrin reagent for the photometric determination of amino acids and related compounds. J Biol Chem 211:907-913

Nadeem SM, Zahir ZA, Naveed M, Arshad M (2007) Preliminary investigations on inducing salt tolerance in maize through inoculation with rhizobacteria containing ACC deaminase activity. Can J Microbiol 53(10):1141-1149

Nadeem SM, Zahir ZA, Naveed M, Nawaz S (2013) Mitigation of salinity-induced negative impact on the growth and yield of wheat by plant growth-promoting rhizobacteria in naturally saline conditions. Ann Microbiol 63(1):225-232

Neales TF (1956) Components of the total magnesium content within the leaves of white clover and perennial ryegrass. Nature 177:388-389

Nustorova M, Braikova D, Gousterova A, Vasileva-Tonkova E, Nedkov P (2006) Chemical, microbiological and plant analysis of soil fertilized with alkaline hydrolysate of sheep's wool waste. World J Microbiol Biotechnol 22(4):383-390

Pandino G, Courts FL, Lombardo S, Mauromicale G, Williamson G (2009) Caffeoylquinic acids and flavonoids in the immature inflorescence of globe artichoke, wild cardoon, and cultivated cardoon. J Agric Food Chem 58(2):1026-1031

Patten CL, Glick BR (2002) Role of Pseudomonas putida indole acetic acid in development of the host plant root system. Appl Environ Microbiol 68(8):3795-3801

Penrose DM, Glick BR (2003) Methods for isolating and characterizing ACC deaminase-containing plant growth-promoting rhizobacteria. Physiol Plant 118(1):10-15

Pikovaskaya RI (1948) Mobilization of phosphorus in soil in connection with vital activity of some microbial species. Microbiol. 17:362-370

Prescott LM, Harley JP, Klein DA (2002) Laboratory exercises in microbiology, 5th edn. McGraw-Hill, New York

Riffel A, Brandelli A, Bellato CDM, Souza GH, Eberlin MN, Tavares FC (2007) Purification and characterization of a keratinolytic metalloprotease from Chryseobacterium sp. kr6. J Biotechnol 128(3):693-703

Ryan J, Estefan G, Rashid A (2007) Soil and plant analysis laboratory manual. ICARDA, Aleppo, Syria

Saha P, Chatterjee P, Biswas AK (2010) NaCl pretreatment alleviates salt stress by enhancement of antioxidant defense system and osmolyte accumulation in mungbean (Vigna radiata L. Wilczek). Indian J Exp Biol 48(6):593

Saitou N, Nei M (1987) The neighbor-joining method: a new method for reconstructing phylogenetic trees. Mol Biol Evol 4(4):406-425

Saravanakumar D, Samiyappan R (2007) ACC deaminase from Pseudomonas fluorescens mediated saline resistance in groundnut (Arachis hypogea) plants. J Appl Microbiol 102(5):1283-1292

Schwyn B, Neilands JB (1987) Universal chemical assay for the detection and determination of siderophores. Anal Biochem 160(1):47-56

Shafi M, Bakhat J, Khan MJ, Khan MA, Anwar S (2010) Effect of salinity on yield and ion accumulation of wheat genotypes. Pak $\mathrm{J}$ Bot 42(6):4113-4121 
Sreenivasulu N, Grimm B, Wobus U, Weschke W (2000) Differential response of antioxidant compounds to salinity stress in salttolerant and salt-sensitive seedlings of foxtail millet (Setaria italica). Physiol Plant 109(4):435-442

Tamura K, Nei M, Kumar S (2004) Prospects for inferring very large phylogenies by using the neighbor-joining method. Proc Natl Acad Sci USA 101(30):11030-11035

Tamura K, Stecher G, Peterson D, Filipski A, Kumar S (2013) MEGA6: molecular evolutionary genetics analysis version 6.0. Mol Biol Evol 30(12):2725-2729

Tiwary E, Gupta R (2010) Medium optimization for a novel $58 \mathrm{kDa}$ dimeric keratinase from Bacillus licheniformis ER-15: biochemical characterization and application in feather degradation and dehairing of hides. Bioresour Technol 101(15):6103-6110

Trivedi P, Pandey A, Palni LMS (2008) In vitro evaluation of antagonistic properties of Pseudomonas corrugata. Microbiol Res 163(3):329-336

Trobacher CP (2009) Ethylene and programmed cell death in plants. Botany 87(8):757-769

Tsavkelova E, Oeser B, Oren-Young L, Israeli M, Sasson Y, Tudzynski B, Sharon A (2012) Identification and functional characterization of indole-3-acetamide-mediated

IAA biosynthesis in plant-associated Fusarium species. Fungal Genet Biol 49(1):48-57

Vernieri P, Borghesi E, Tognoni F, Serra G, Ferrante A, Piagessi A (2006) Use of biostimulants for reducing nutrient solution concentration in floating system. In: III international symposium on models for plant growth, environmental control and farm management in protected cultivation, vol 718, pp 477-484

Wang SL, Hsu WT, Liang TW, Yen YH, Wang CL (2008) Purification and characterization of three novel keratinolytic metalloproteases produced by Chryseobacterium indologenes TKU014 in a shrimp shell powder medium. Bioresour Technol 99(13):5679-5686

Williams CM, Richter CS, Mackenzie JM, Shih JC (1990) Isolation, identification, and characterization of a feather-degrading bacterium. Appl Environ Microbiol 56(6):1509-1515

Yang J, Kloepper JW, Ryu CM (2009) Rhizosphere bacteria help plants tolerate abiotic stress. Trends Plant Sci 14(1):1-4

Yuan J, Ruan Y, Wang B, Zhang J, Waseem R, Huang Q, Shen Q (2013) Plant growth-promoting rhizobacteria strain Bacillus amyloliquefaciens NJN-6-enriched bio-organic fertilizer suppressed Fusarium wilt and promoted the growth of banana plants. J Agric Food Chem 61(16):3774-3780 